\title{
Homeobox Protein SIX1
}

National Cancer Institute

\section{Source}

National Cancer Institute. Homeobox Protein SIX1. NCI Thesaurus. Code C84414.

Homeobox protein SIX1 (284 aa, $\sim 32 \mathrm{kDa}$ ) is encoded by the human SIX1 gene. This protein may be involved in the modulation of limb development. 